\title{
Synergy between CALIOP and MODIS instruments for aerosol monitoring: application to the Po Valley
}

\author{
P. Royer ${ }^{1,2}$, J.-C. Raut $^{3, *}$, G. Ajello ${ }^{1}$, S. Berthier ${ }^{1, * *}$, and P. Chazette ${ }^{1,3}$ \\ ${ }^{1}$ Laboratoire des Sciences du Climat et de l'Environnement (LSCE), Laboratoire mixte CEA-CNRS-UVSQ, UMR 1572, \\ CEA Saclay, 91191 Gif-sur-Yvette, France \\ ${ }^{2}$ LEOSPHERE, 76 rue de Monceau, 75008 Paris, France \\ ${ }^{3}$ Laboratoire de Météorologie Dynamique (LMD), UMR 8539, Ecole Polytechnique, 91128 Palaiseau, France \\ * now at: Laboratoire Atmosphères Milieux Observations Spatiales (LATMOS), Laboratoire mixte CNRS-UVSQ-UPMC, \\ UMR 8190, Université Paris 6, 4 Place Jussieu 75252 Paris, France \\ ** now at: Koninklijk Nederlands Meteorologisch Instituut (KNMI), De Bilt, The Netherlands
}

Received: 10 February 2010 - Published in Atmos. Meas. Tech. Discuss.: 29 March 2010

Revised: 15 June 2010 - Accepted: 22 June 2010 - Published: 9 July 2010

\begin{abstract}
In this study aerosol optical properties are studied over the Po Valley from June 2006 to February 2009 using Cloud-Aerosol Lidar and Infrared Pathfinder Satellite Observations/Cloud-Aerosol LIdar with Orthogonal Polarization (CALIPSO/CALIOP) and Moderate Resolution Imaging Spectroradiometer (MODIS) onboard Aqua and Terra. The choice of the Po valley has been driven by the numerous occurrences of pollutant events leading to a mean MODIS-derived aerosol optical depth (AOD) of $0.27( \pm 0.17)$ at $550 \mathrm{~nm}$ over a large area of $\sim 120000 \mathrm{~km}^{2}$. AOD derived from MODIS, AERONET and CALIOP have been compared. The comparison with AERONET sunphotometers has highlighted an overestimation of AOD from MODIS radiometers of 0.047 for Aqua and 0.088 for Terra. A systematic underestimation of AOD derived from CALIOP Level-2 products has been observed in comparison to Aqua (0.060) and Terra (0.075) MODIS values. Considering those discrepancies a synergistic approach combining CALIOP level-1 data and MODIS AOD has been developed for the first time over land to retrieve the equivalent extinction-tobackscatter ratio at $532 \mathrm{~nm}$ (LR). MODIS-derived AOD were indeed used to constrain CALIOP profiles inversion. A significant number of CALIOP level-1 vertical profiles have been averaged ( 200 individual laser shots) in the Po Valley, leading to a signal-to-noise ratio (SNR) higher than 10 in the planetary boundary layer (PBL), which is suffi-
\end{abstract}

cient to invert the mean lidar profiles. The mean LR (together with the associated variabilities) over the Po Valley retrieved from the coupling between CALIOP/MODIS-Aqua and CALIOP/MODIS-Terra are $\sim 78 \pm 22 \mathrm{sr}$ and $\sim 86 \pm 27 \mathrm{sr}$, respectively. The total uncertainty on $\mathrm{LR}$ retrieval has been assessed to be $\sim 12 \mathrm{sr}$ using a Monte Carlo approach. The mean LR determined from a look-up table through a selection algorithm in CALIOP level 2 operational products ( $\sim 63 \pm 8 \mathrm{sr}$ ) show a good agreement for daytime inversion ( $70 \pm 11 \mathrm{sr}$ for Aqua and $74 \pm 14 \mathrm{sr}$ for Terra). These values appear close to what is expected for pollution aerosols in an urban area. Contrarily large differences are observed when considering nighttime CALIOP profiles inverted with daytime AOD from MODIS (63 \pm 7 sr for CALIOP level-2 compared with $89 \pm 28$ sr for CALIOP/Aqua and $103 \pm 32 \mathrm{sr}$ for CALIOP/Terra synergies). They can be explained by a significant evolution of AOD between lidar and radiometer passing times. In most of cases, the mean aerosol extinction coefficient in the PBL significantly differs between the level2 operational products and the result CALIPSO/MODIS synergy results. Mean differences of $0.10 \mathrm{~km}^{-1}(\sim 50 \%)$ and $0.13 \mathrm{~km}^{-1}(\sim 60 \%)$ have indeed been calculated using MODIS-Aqua/CALIOP and MODIS-Terra/CALIOP coupling studies, respectively. Such differences may be due to the identification of the aerosol model by the operational algorithm and thus to the choice of the LR.

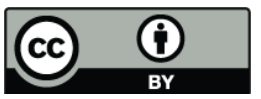

Correspondence to: P. Royer (philippe.royer@1sce.ipsl.fr)

Published by Copernicus Publications on behalf of the European Geosciences Union. 


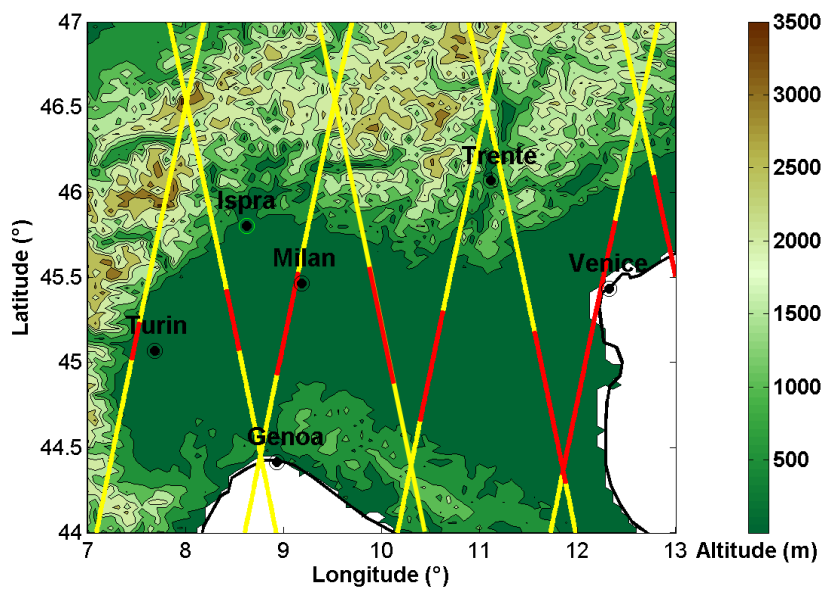

Fig. 1. Main cities and topography of the Po Valley region. The yellow solid lines represent the ground-tracks of CALIPSO orbits that have been considered. The red sections highlight the useful part of the orbits with a mean sea level (MSL) altitude lower than $0.2 \mathrm{~km}$.

\section{Introduction}

Aerosol pollution study in the greatest urban centers is of increasing interest as it directly concerns half of the world population. Moreover, a continuous development of huge cities in the future 40 years would constrain two thirds of the world population to live into megacities or close to industrial areas. Now, it has been clearly established that small particles with a radius lower than $2.5 \mu \mathrm{m}\left(\mathrm{PM}_{2.5}\right)$ increase cardiovascular troubles (e.g. Dockery and Pope, 1996; Lauwerys et al., 1982). Several studies have also shown that megalopolis had a regional impact on air quality and climate (e.g. Lawrence et al., 2007). The study of these areas is thus important to improve our understanding of physical and chemical processes that play a key role on pollution peaks. This will help improving chemistry-transport models, defining more accurate scenarios of emission mitigation and improving the forecast of pollution events.

The new generation of spaceborne missions is a new insight to follow pollution levels over the whole atmosphere and over specific areas where human activities have significantly modified the natural equilibrium. The synergy between active and passive remote sensing instruments is a powerful tool in atmospheric studies dedicated to the evaluation of human impact. The A-train Satellite Constellation (Afternoon Constellation) is a significant part of these new approaches and lets to consider the future spaceborne missions using instrumental synergy from space.

Instrumental synergies have already proved their ability to retrieve aerosol optical properties with a good accuracy. Ground-based synergies involving lidar and sun-photometer have been used in the framework of the INDian Ocean EXperiment (INDOEX) to determine aerosol optical properties
(Chazette, 2003). A similar approach has been used in the Lidar pour la surveillance de l'AIR (LISAIR) program around Paris area (Raut and Chazette, 2007). During the African Multidisciplinary Monsoon Analysis (AMMA) campaign, the aerosol radiative budget has been assessed using airborne lidar and in situ measurements together with a ground-based sunphotometer (e.g. Raut and Chazette, 2008b; Haywood et al., 2008). Raman lidar combined with passive remote sensing can give access to microphysical aerosol properties (e.g. Balis et al., 2010). During previous campaigns, the passive/active instrumental synergy has also been used onboard an aircraft (e.g. Pelon et al., 2002) or involving airborne and spaceborne measurements (e.g. Chazette et al., 2001; Dulac and Chazette, 2003). A spaceborne synergy between $\mathrm{Li}^{-}$ dar in-Space Technology Experiment (LITE) and Meteosat has also been used to determine dust properties over deserts (Berthier et al., 2006) and has thus shown the interest of such an approach. Liu et al. (2008) used optical depth constraint method with CALIOP data over ocean to retrieve optical properties of Saharan dust during a long-range transport. Aerosol single-scattering albedo for biomass-burning smoke has been determined using a synergy between A-train sensors (Jeong et al., 2008).

The Po Valley is a large European polluted areas of $\sim 120000 \mathrm{~km}^{2}$ oriented east-west with a mean width of $\sim 100 \mathrm{~km}$. It is then particularly suitable for spatial studies using the synergy between Cloud-Aerosol Lidar and Infrared Pathfinder Satellite Observations/Cloud-Aerosol LIdar with Orthogonal Polarization (CALIPSO/CALIOP) and Moderate Resolution Imaging Spectroradiometer onboard Aqua (MODIS-Aqua) and Terra (MODIS-Terra).

The Po valley is among the most polluted area in Western Europe. The presence of large cities, the high density of industries and population (more than 100 people per $\mathrm{km}^{2}$ ), the presence of mountains surrounding this region (the Alps in the north and the west, and the Apennines in the south) concentrate the pollutants in the planetary boundary layer (PBL) and lead to a high aerosol loading particularly in summer with a mean optical thickness close to 0.4 at $550 \mathrm{~nm}$ (e.g. Barnaba and Gobbi, 2004). Figure 1 shows the topography and the location of the main cities in the Po valley. Many scientific studies and specific campaigns have been conducted in the Po Valley, such as Pianura Padana ozone production (PIPAPO; Neftel et al., 2002), Pollution hot-spot monitoring from GOME applied to the Po basin (POLPO; Petritoli et al., 2004), Quantification of aerosol nucleation in the European boundary layer (QUEST; Laaksonen et al., 2005) and Aerosol Direct Radiative Experiment (ADRIEX; Highwood et al., 2007).

The instruments used in this study are presented in Sect. 2. In Sect. 3, the aerosol optical depth from MODIS radiometers over the Po Valley is analyzed and compared with AOD derived from AERONET sun-photometer stations and CALIOP level-2 data. The synergistic approach used to constraint CALIOP lidar profiles with AOD from MODIS 
radiometers as well as the error analysis are described in Sect. 4. Finally LR and aerosol extinction coefficients retrieved over the Po Valley are presented and discussed in Sect. 5.

\section{Observations}

\subsection{CALIPSO/CALIOP lidar}

CALIOP is a spaceborne nadir-pointing lidar launched on 28 April 2006 aboard CALIPSO satellite (http://www-calipso. larc.nasa.gov) to join the Afternoon Constellation (A-train, Stephens et al., 2002). Its $705 \mathrm{~km}$-height sun-synchronous orbit has a repetitivity of 16 days. The laser emission is based on a diode-pumped Nd:YAG producing linearly-polarized pulses of light at 1064 and $532 \mathrm{~nm}$ with a mean pulse energy of $110 \mathrm{~mJ}$ and a repetition rate of $20.25 \mathrm{~Hz}$ i.e. a horizontal resolution of $333 \mathrm{~m}$ (Winker et al., 2003). The receiver is composed of a $1-\mathrm{m}$ telescope and three detectors to measure the backscattered signal at $1064 \mathrm{~nm}$ and the parallel and perpendicular components of the $532 \mathrm{~nm}$ return. The high vertical resolution of CALIOP lidar $(30-60 \mathrm{~m})$ provides information over land and ocean on optical, physical and structural properties of aerosols (e.g. Thomason et al., 2007; Kim et al., 2008) and clouds (e.g. Sassen et al., 2008; Berthier et al., 2008; Noel et al., 2008).

In this study, we have employed both the total attenuated backscatter coefficient at $532 \mathrm{~nm}\left(\beta^{\text {att }}\right)$ from CALIOP level-1 calibrated data product and the aerosol extinction $\left(\alpha_{a}\right)$ and backscatter $\left(\beta_{a}\right)$ coefficients at $532 \mathrm{~nm}$ from level2 aerosol products (http://eosweb.larc.nasa.gov/PRODOCS/ calipso/table_calipso.html). Level-1 data have a high horizontal resolution $(\sim 0.3 \mathrm{~km})$, whereas the level-2 data are given with a mean profile averaged over $40 \mathrm{~km}$.

The CALIOP operational retrieval of $\alpha_{a}$ is computed using an aerosol extinction-to-backscatter ratio (LR) determined with the selection algorithm described in the Scene Classification Algorithms (PC-SCI-202.03) of the CALIOP Lidar Level II Algorithm Theoretical Basis Document (ATBD). Aerosol extinction profiles are given with a vertical resolution of $120 \mathrm{~m}$ from the ground up to $8.2 \mathrm{~km}$ above the mean sea level (a.m.s.l.). The aerosol type is determined in each layer using a model-matching scheme (Omar, 2009). Optical (attenuated backscatter coefficient at $532 \mathrm{~nm}$, and depolarization ratio), geographical (e.g. latitude, longitude, surface type), aerosol layer elevation, and temporal (season) characteristics are used to select the most likely LR for each layer. There are 6 different aerosols types: polluted continental ( $\mathrm{LR}=70 \mathrm{sr}$ at $532 \mathrm{~nm}$ ), biomass burning ( $\mathrm{LR}=70 \mathrm{sr}$ ), desert dust $L R=40 \mathrm{sr}$ ), polluted dust ( $\mathrm{LR}=65 \mathrm{sr}$ ), clean continental $(\mathrm{LR}=35 \mathrm{sr})$ and marine ( $\mathrm{LR}=20 \mathrm{sr})$. The uncertainties on aerosol backscatter and extinction coefficients are respectively $20-30 \%$ and $40 \%$ assuming an uncertainty of $30 \%$ on LR (Omar, 2009).
A total of 461 CALIPSO orbits have passed over the Po Valley between 13 June 2006 and 15 February 2009 at around 01:30 and 12:30 GMT for nighttime and daytime tracks, respectively. The CALIPSO orbits considered (yellow solid lines) and the portions in the Po Valley with an altitude lower than $200 \mathrm{~m}$ (red solid lines) are represented in Fig. 1. Among those 461 orbits only 118 (i.e. 25.6\%) were obtained in cloud-free conditions. Each orbit has been connected with the nearest big city flew over by CALIPSO. Table 1 shows the apportionment of these orbits as a function of cities and seasons. This distribution is globally homogeneous in space and time, which is important so as to potentially determine a seasonal trend.

\subsection{MODIS radiometers onboard TERRA and AQUA}

Moderate Resolution Imaging Spectroradiometers (MODIS, Salmonson et al., 1989; King et al., 1992) are aboard Aqua and Terra plateforms. Aqua has joined the A-train constellation on December 1999 whereas Terra has been launched on May 2002. The polar orbit of Terra (http://terra.nasa.gov) passes over the equator from north to south in the morning, whereas Aqua (http://aqua.nasa.gov) has ascending node over the equator during the afternoon. The MODIS radiometers are composed of 36 spectral bands, or groups of wavelengths from $400 \mathrm{~nm}$ to $1440 \mathrm{~nm}$. Their wide swaths of $110^{\circ}$ (i.e. $2330 \mathrm{~km}$ ) provide a global coverage of Earth's surface from one to two days with a resolution between 250 and $1000 \mathrm{~m}$ at ground level depending on the band.

We used here the aerosol optical depth (AOD) at $550 \mathrm{~nm}$ $\left(\tau_{\mathrm{MO}}\right)$ from MODIS aerosol product level-2 data for Terra and Aqua platforms. Both products are given with a spatial resolution of $10 \times 10 \mathrm{~km}^{2}$ at nadir. The standard deviation on $\tau_{\mathrm{MOi}}$ retrieval over land above the pixel $i$ is $\sigma_{\mathrm{MOi}}=$ $\pm 0.05 \pm 0.2 \tau_{\mathrm{MOi}}$ (Chu et al., 2002). MODIS data are taken from June 2006 to February 2009.

\subsection{AERONET sun-photometers}

The AErosol RObotic NETwork (AERONET) is an automatic and global network of sun-photometers which provides long-term and continuous monitoring of aerosol optical, microphysical and radiative properties (http://aeronet. gsfc.nasa.gov/). Each site is composed of a sun and sky scanning spectral radiometer manufactured by CIMEL. For direct sun measurement eight spectral bands are used between 340 and $1020 \mathrm{~nm}$. The five standard wavelengths are 440, 670, 870, 940 and $1020 \mathrm{~nm}$. AOD data are computed for three data quality levels: level 1.0 (unscreened), level 1.5 (cloud-screened), and level 2.0 (cloud screened and quality-assured). The total uncertainty on AOD is $< \pm 0.01$ for $\lambda>440 \mathrm{~nm}$ and $< \pm 0.02$ for $\lambda<440 \mathrm{~nm}$ (Holben et al., 1998). Three AERONET sun-photometers are located in the Po Valley at Modena, Ispra and Venice sites. We only used here level 2.0 data from Ispra station at $500 \mathrm{~nm}$. 
Table 1. Seasonal and spatial distributions of CALIOP level-1 data in cloud-free conditions over the Po Valley from June 2006 to February 2009. The nearest big cities flew over by CALIPSO are given with their numbers of inhabitants and the main aerosol sources. The mean number of profiles and the corresponding SNR in the PBL are also specified for each orbit.

\begin{tabular}{|c|c|c|c|c|c|c|c|c|}
\hline \multicolumn{2}{|c|}{ Seasons } & \multirow{2}{*}{$\begin{array}{l}\text { Milan } \\
2\end{array}$} & \multirow{2}{*}{$\begin{array}{l}\text { Turin } \\
0\end{array}$} & \multirow{2}{*}{$\begin{array}{l}\text { Genoa } \\
3\end{array}$} & \multirow{2}{*}{$\begin{array}{l}\text { Bologna } \\
-\end{array}$} & \multirow{2}{*}{$\begin{array}{l}\text { Venice } \\
3\end{array}$} & \multirow{2}{*}{$\begin{array}{l}\text { Trente } \\
2\end{array}$} & \multirow{2}{*}{$\begin{array}{l}\text { Total } \\
10\end{array}$} \\
\hline 2006 & JJA & & & & & & & \\
\hline & SON & 3 & 0 & 4 & - & 0 & 3 & 10 \\
\hline \multirow[t]{4}{*}{2007} & DJF & 3 & 1 & 1 & - & 2 & 4 & 11 \\
\hline & MAM & 3 & 0 & 2 & - & 4 & 4 & 13 \\
\hline & JJA & 1 & 1 & 1 & - & 3 & 5 & 11 \\
\hline & SON & 3 & 1 & 1 & - & 4 & 5 & 14 \\
\hline \multirow[t]{4}{*}{2008} & DJF & 4 & 1 & 3 & - & 6 & 3 & 17 \\
\hline & MAM & 1 & 1 & 1 & - & 1 & 0 & 4 \\
\hline & JJA & 3 & 1 & 1 & - & 1 & 3 & 9 \\
\hline & SON & 2 & 0 & 3 & - & 4 & 1 & 10 \\
\hline 2009 & DJF & 3 & 0 & 2 & - & 3 & 1 & 9 \\
\hline \multicolumn{2}{|c|}{ Total } & 28 & 6 & 22 & - & 31 & 31 & 118 \\
\hline \multicolumn{2}{|c|}{$\begin{array}{c}\text { Number } \\
\text { of inhabitants }\end{array}$} & 750000 & 2200000 & 880000 & 375000 & 270000 & 115000 & 4590000 \\
\hline \multicolumn{2}{|c|}{$\begin{array}{l}\text { Main sources of } \\
\text { pollution aerosols }\end{array}$} & $\begin{array}{l}\text { traffic } \\
\text { textile } \\
\text { mech. } \\
\text { chemical } \\
\text { w.\&p. } \\
\text { meta. }\end{array}$ & $\begin{array}{l}\text { traffic } \\
\text { mech. } \\
\text { textile } \\
\text { chemical } \\
\text { w.\&p. } \\
\text { meta. }\end{array}$ & $\begin{array}{l}\text { traffic } \\
\text { mech. } \\
\text { textile } \\
\text { chemical } \\
\text { meta. }\end{array}$ & $\begin{array}{l}\text { traffic } \\
\text { mech. } \\
\text { chemical } \\
\text { building } \\
\text { material }\end{array}$ & $\begin{array}{l}\text { textile } \\
\text { meta. } \\
\text { chemical } \\
\text { building }\end{array}$ & $\begin{array}{l}\text { mech. } \\
\text { meta. }\end{array}$ & \\
\hline \multirow{2}{*}{$\begin{array}{l}\text { Number of } \\
\text { profiles }\end{array}$} & day & $191 \pm 38$ & - & $154 \pm 42$ & - & $151 \pm 32$ & $292 \pm 90$ & $202 \pm 84$ \\
\hline & night & $186 \pm 32$ & $60 \pm 11$ & - & - & $438 \pm 108$ & $199 \pm 59$ & $265 \pm 153$ \\
\hline \multirow[t]{2}{*}{ SNR } & day & $15 \pm 5$ & - & $12 \pm 4$ & - & $13 \pm 4$ & $16 \pm 5$ & $14 \pm 4$ \\
\hline & night & $22 \pm 3$ & $12 \pm 3$ & - & - & $34 \pm 7$ & $23 \pm 4$ & $25 \pm 9$ \\
\hline
\end{tabular}

mech. = mechanical; w.\&p. = wood and paper; meta. = metallurgical.

\section{Aerosol optical depth over the Po Valley}

\subsection{MODIS observations}

An example of aerosol optical depth map derived over the Po Valley from MODIS Aqua and Terra instruments for the 16 March 2007 is shown on Fig. 2a and b, respectively. This particularly high-polluted day is characterized by anticyclonic conditions with a mean temperature of $\sim 20^{\circ} \mathrm{C}$ close to the surface. The weak southern wind $\left(\sim 6 \mathrm{~m} . \mathrm{s}^{-1}\right)$ sweeps pollutants northerly where they are stopped by the Alps and thus leads to higher AOD values in the northern part of the Po Valley (AOD larger than 1 near Venice). The mean AOD values derived from Aqua and Terra (with their variabilities) under CALIPSO track are $0.54( \pm 0.15)$ and $0.47( \pm 0.13)$ at $550 \mathrm{~nm}$, respectively. Although Aqua and Terra instruments are only separated by $1 \mathrm{~h}$ and $40 \mathrm{~min}$, a significant evolution in the AOD pattern can be observed. Nevertheless, the mean values along the CALIPSO ground track are very similar within a margin of $\sim 14 \%$.
The temporal evolution of aerosol optical depth $\tau_{\text {MO }}$ over the Po Valley has been calculated as the mean AOD at $550 \mathrm{~nm}$ from MODIS-Aqua (Fig. 3a) and Terra (Fig. 3b) radiometers in a $10 \mathrm{~km}$-radius around the CALIPSO track. The individual AOD measured at pixel $i\left(\tau_{\mathrm{MOi}}\right)$ have been weighted by the minimal distance $d_{i}$ between the pixel centre and CALIPSO track, as:

$\tau_{\mathrm{MO}}=\frac{\sum_{i=1}^{p} d_{i}^{-1} \cdot \tau_{\mathrm{MOi}}}{\sum_{i=1}^{p} d_{i}^{-1}}$

with $p$ the number of pixels taken into account in the vicinity of CALIPSO track.

With the reasonable assumption of statistical independence between pixels (i.e. $\tau_{\mathrm{MOi}}$ and $\tau_{M O j}$ are independent for $\mathrm{i} \neq \mathrm{j}$ ), the standard deviation $\sigma_{\mathrm{MO}}$ on $\tau_{\mathrm{MO}}$ is then given as a function of the individual standard deviations $\sigma_{\mathrm{MOi}}$ by:

$\sigma_{\mathrm{MO}}=\sqrt{\frac{\sum_{i=1}^{p} d_{i}^{-2} \cdot \sigma_{\mathrm{MOi}}^{2}}{\left(\sum_{i=1}^{p} d_{i}^{-1}\right)^{2}}}$ 
(a)

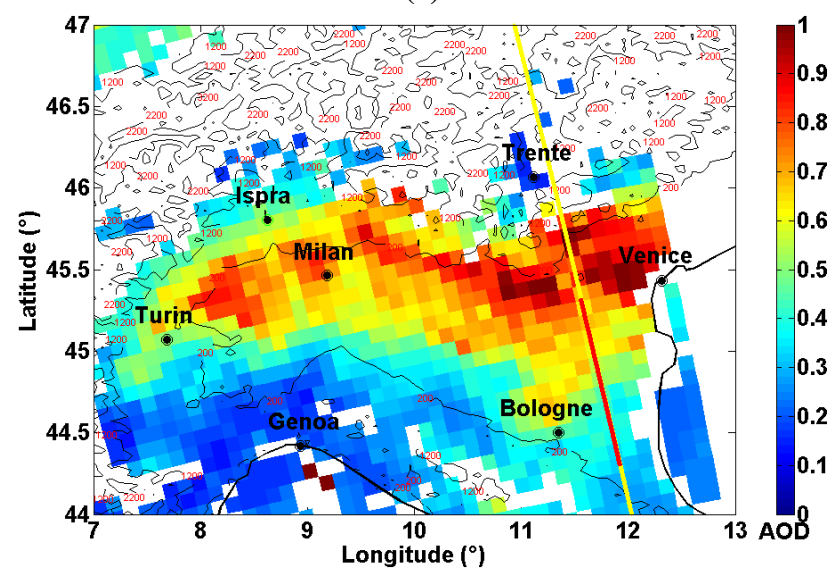

(b)

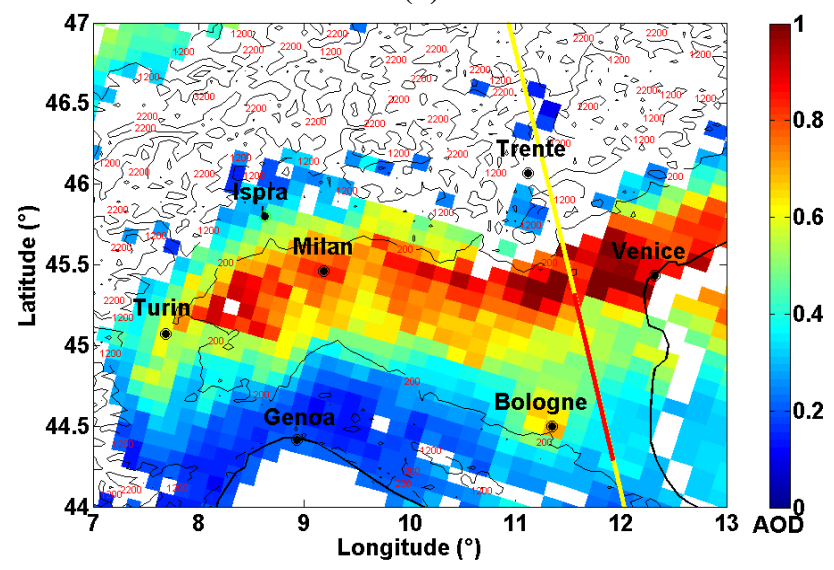

Fig. 2. AOD map at $550 \mathrm{~nm}$ over the Po Valley on the 16 March 2007 from (a) MODIS-Aqua at 12:20 UTC and (b) MODIS-Terra at 10:40 UTC. The topography levels around the Po valley are shown in black lines. The yellow solid line represents the ground-track of CALIPSO orbits that have been considered and the red section highlights the useful part of the orbits with an altitude lower than $0.2 \mathrm{~km}$ a.m.s.1.

A total of 102 and 104 coincidences between CALIOP and MODIS have been considered for Aqua and Terra, respectively. A high variability of $\tau_{\mathrm{MO}}$ is observed with a mean value close to 0.25 . A seasonal cycle is clearly visible, mainly for MODIS-Terra, as already described by Mélin and Zibordi (2005) and Barnaba and Gobbi (2004). The lower AOD observed in winter and fall can be explained by an increase in precipitations involving a wet deposition removal and thus a decrease in the aerosol load. In summer, the high temperatures and a lack of precipitations contribute to increase the aerosol loads in the PBL. The mean annual AOD observed over the Po Valley $(\sim 0.27)$ is almost twice higher than that measured from sunphotometer observation over Paris, which is $\sim 0.15$ at $532 \mathrm{~nm}$, as shown by Chazette et al. (2005). Other authors report such high AOD values over (a)

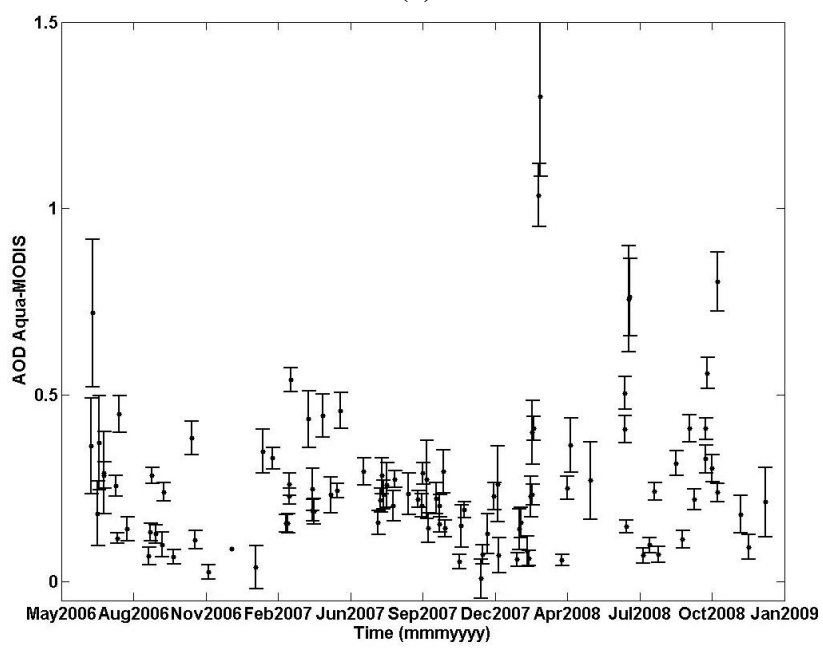

(b)

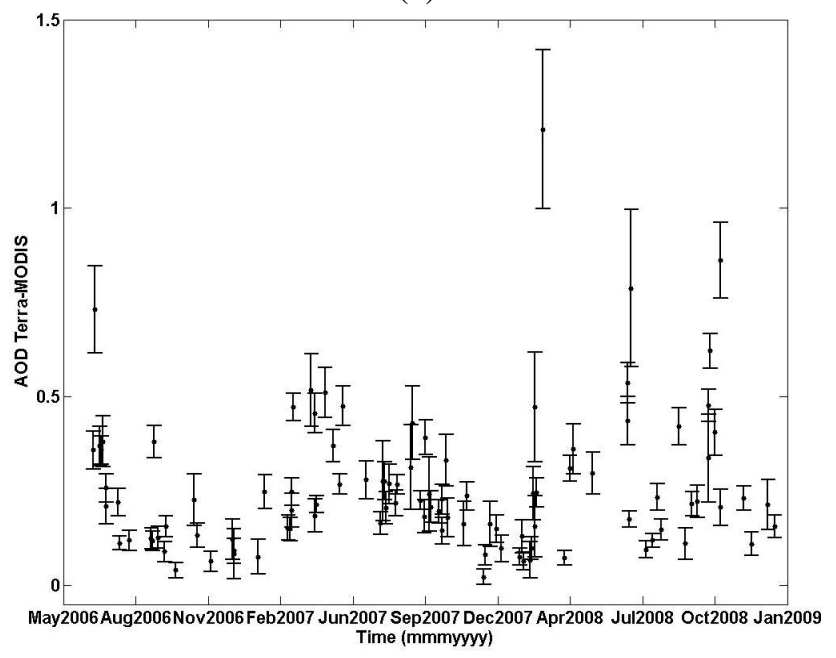

Fig. 3. Temporal evolution of the mean AOD at $550 \mathrm{~nm}$ ( $\left.\tau_{\mathrm{MO}}\right)$ under CALIPSO ground track between June 2006 and February 2009 from (a) MODIS-Aqua (102 data) and (b) MODIS-Terra (104 data) for the situations where both CALIOP and MODIS data are available. The errorbars represent the standard deviation $\sigma_{\mathrm{MO}}$ associated with each AOD value.

great urban and industrial areas (e.g. Kim et al. (2007) found 0.33 at 550 nm over East Asia, Ramachandran (2007) 0.4 and 0.65 at $550 \mathrm{~nm}$ over Mumbai and New Delhi, Stammes and Henzing (2000) 0.26 at $501 \mathrm{~nm}$ over De Bilt (Netherlands)).

\subsection{Comparison MODIS/Aeronet}

The existence of a systematic bias on MODIS-derived AOD at $550 \mathrm{~nm}$ has been assessed from a comparison with the AERONET sunphotometer at Ispra between June 2006 and November 2008 (Fig. 4). Data from the sun-photometer of Venice, located on the Acqua Alta Oceanographic Tower (AAOT) 8 nautical miles off the Venice Lagoon, have not 


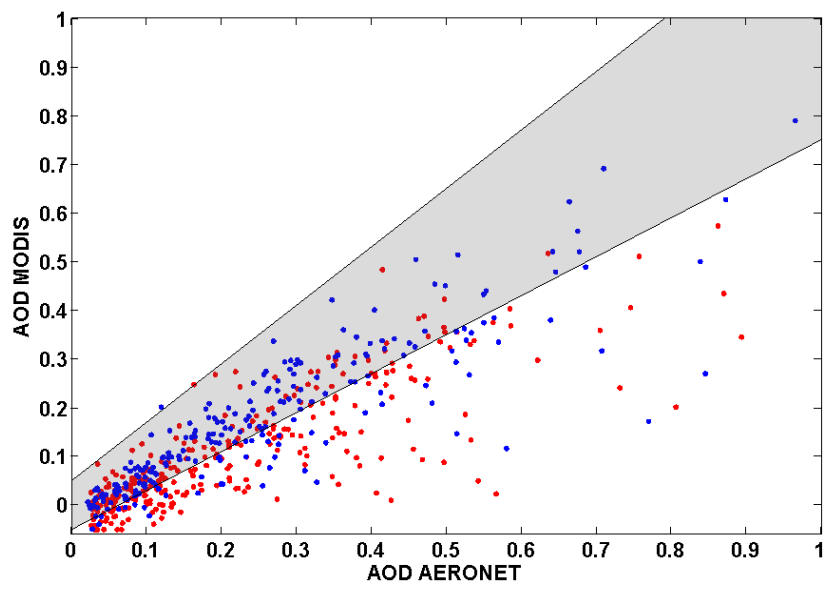

Fig. 4. Comparison of AOD values between June 2006 and November 2008 retrieved from MODIS-Terra (249 red dots) and Aqua (210 blue dots) instruments at $550 \mathrm{~nm}$, and Ispra AERONET sunphotometer. The sunphotometer-derived AOD $\tau_{\text {MO }}$ at $550 \mathrm{~nm}$ have been calculated using the Angström exponent between 500 and $675 \mathrm{~nm}$. The gray shaded area represents the standard deviation $\sigma_{\mathrm{MO}}= \pm 0.05 \pm 0.2 \tau_{\mathrm{MO}}$ on MODIS radiometers.

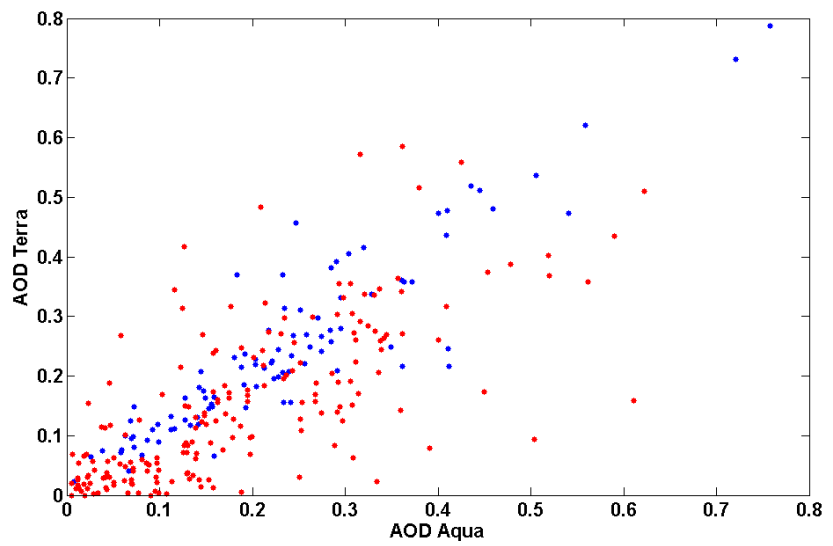

Fig. 5. Intercomparison of the mean MODIS-derived AOD along the CALIPSO tracks (96 blue dots) and near Ispra site (233 red dots) when considering Terra and Aqua platforms.

been used because of subpixel water contamination in continental coastal regions (Chu et al., 2002). Hence, this station is not representative of the aerosol features found over the Po Valley. The sunphotometer-derived AOD at $550 \mathrm{~nm}$ have been interpolated using the Angström exponent (Angström, 1964 ) between 500 and $670 \mathrm{~nm}$. MODIS-derived AOD are computed using a weighted mean of pixels with a centre located at a distance lower than $10 \mathrm{~km}$ around Ispra station.

The agreement between MODIS-derived AOD and AERONET sunphotometer-derived AOD is better when Aqua satellite is considered. The corresponding correlation coefficient is 0.89 . Nevertheless, this value is associated with a mean bias of 0.047. When MODIS-Terra is consid-

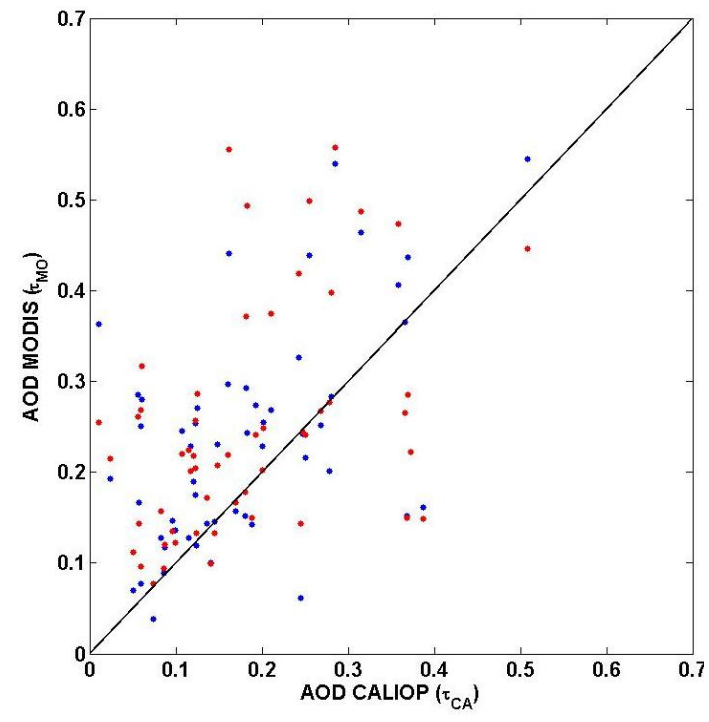

Fig. 6. Comparison between of AOD derived from CALIOP $\left(\tau_{\mathrm{CA}}\right)$ and from MODIS ( $\left.\tau_{\mathrm{MO}}\right)$ Aqua (blue dots) or Terra (red dots).

ered, the correlation coefficient is 0.87 and the bias is larger $(\sim 0.088)$. When comparing $\tau_{\mathrm{MO}}$ retrieved from MODISTerra and Aqua around Ispra station (Fig. 5) the previous biases are confirmed. MODIS-Terra slightly overestimates the AOD by 0.037 compared with MODIS-Aqua.

\subsection{Comparison of AOD derived from MODIS and CALIOP instruments}

Aerosol optical depth derived from MODIS radiometers $\left(\tau_{\mathrm{MO}}\right)$ and CALIOP level 2 products lidar $\left(\tau_{\mathrm{CA}}\right)$ has been compared under CALIOP track over the Po Valley. Figure 6 shows the results for both Aqua (blue dots) and Terra (red dots) radiometers. We can notice a quasi-systematic underestimation of CALIOP-derived AOD compared with Aqua and Terra AOD (for $\sim 70 \%$ of cases). The mean AOD values are respectively $0.234,0.249$ and 0.174 for Aqua, Terra and CALIOP. Considering these discrepancies a synergistic approach using CALIOP level-1 data has been developed to retrieve the equivalent extinction-to-backscatter ratio at $532 \mathrm{~nm}$ (LR) constrained by MODIS-derived AOD. This inversion algorithm and the uncertainty assessment are presented in the following section.

\section{Determination of Lidar Ratio from the synergy between CALIOP lidar and MODIS radiometers}

\subsection{Synergistic method description}

The total attenuated backscatter coefficient $\left(\beta^{\text {att }}\right)$ from lidar measurements can be written against the distance $s$ under the 
form (Measures, 1984):

$\beta^{\text {att }}(s)=K\left(\beta_{m}(s)+\beta_{a}(s)\right) \cdot \exp \left\{-2 \int_{0}^{s}\left(\alpha_{m}\left(s^{\prime}\right)+\alpha_{a}\left(s^{\prime}\right)\right) d s^{\prime}\right\}$

$K$ represents the system constant that is eliminated through normalization at an altitude where only molecular scattering occurs (so-called Rayleigh zone). The molecular extinction and backscatter coefficients $\alpha_{m}$ and $\beta_{m}$ can be determined from radiosoundings or climatic data of temperature and pressure so that only aerosol contributions require determination. Hence, the lidar equation is an ill-posed problem requiring the retrieval of two unknowns the aerosol extinction and backscatter coefficient $\alpha_{a}$ and $\beta_{a}$.

Different algorithms have been proposed to solve the previous equation using exogenous constraints or specific measurement geometries. LR can be (i) estimated thanks to an a priori knowledge on the aerosol, or calculated (ii) from multi-angular measurements (Sicard et al., 2002), (iii) from the coupling between elastic and Raman channels (Ansmann et al., 1992), (iv) from different geometries of lidar observations (Chazette et al., 2007) or (v) from a synergy with a passive instrument measuring the total AOD as a sunphotometer (Chazette, 2003). The latter has been also successfully used considering the synergy between airborne lidar and Meteosat observations in Chazette et al. (2001) and in Dulac and Chazette (2003), and between the spaceborne lidar LITE and the geostationary satellite Meteosat in Berthier et al. (2006) to retrieve dust aerosol optical properties over ocean or continent.

Here we consider the coupling between the passive instrument MODIS and the spaceborne lidar CALIOP. A similar approach has been developed by Berthier et al. (2006) using LITE and Meteosat. After removing of CALIOP cloudy profiles, CALIOP and MODIS AOD ( $\left.\tau_{\mathrm{MO}}\right)$ data are averaged along the red portions of CALIOP track in the Po Valley (Fig. 1). An individual CALIOP level-1 profile is associated to a signal-to-noise ratio (SNR) in the PBL close to 1.5 (e.g. Berthier et al., 2008). It is not enough to retrieve the aerosol extinction profile. A significant part of the CALIPSO orbit has been therefore averaged in terms of lidar profiles. Regarding at topographic issues, the number of individual lidar profiles averaged depends on the orbit considered. The resulting SNR of the mean CALIOP profile is ranging from 6 to 43 with a mean value of $\sim 18$ in the PBL after applying a low-pass filtering on the lidar data reducing the lidar vertical resolution to $\sim 100 \mathrm{~m}$. Table 1 summarizes the mean number of CALIOP level-1 individual lidar profiles averaged and the mean SNR in the vicinity of each site, together with their standard deviation. The mean CALIOP profile is then inverted with a classical Klett algorithm (Klett, 1985) and requires a dichotomous approach on LR values converging when the difference between CALIOP and MODIS derived AOD is lower than 0.01. Such a value has been established for a relative residual error on LR lower than $3 \%$. AOD de- rived from Aqua and Terra-MODIS used for the inversion are previously corrected from the bias observed in Sect. 3.2 assuming that AERONET sunphotometer-derived AOD are closer to the true values.

It is important to note that this approach only gives access to a height-independent LR. In presence of several aerosol layers, this column-averaged value can be significantly different from the LR in each layer (case of dust aerosols above the PBL for example). It is also noteworthy that CALIPSO and Aqua or Terra are not exactly coincident in time. The aerosol loads and characteristics can evolve between CALIOP and Aqua or Terra measurements. This is particularly crucial when the nocturnal orbits of CALIPSO are considered since AOD constraints are always provided by MODIS data acquired on daytime. This effect will be discussed later in Sect. 5.1. The different sources of uncertainties of this synergistic approach are detailed and analyzed in the following section.

\subsection{Uncertainties on LR}

The different sources of uncertainty on the lidar-derived aerosol extinction coefficient $\left(\alpha_{a}\right)$ are well described in Chazette et al. (1995). Uncertainties in the determination of $\alpha_{a}$ can be related to five main causes: (1) the uncertainty on the a priori knowledge of the vertical profile of the molecular backscatter coefficient as determined from ancillary measurements, (2) the uncertainty on the lidar signal in the altitude range used for the normalization, (3) the uncertainty on LR and on its altitude dependence, (4) the statistical fluctuations in the measured signal, associated with random detection processes, and (5) the overall uncertainty resulting from the value of $\tau_{\mathrm{MO}}$ defined in Eq. (1).

The mean lidar profiles have been calibrated in a region deemed to be free from aerosols. SNR in the Rayleigh zone has been calculated to be higher than 20. The uncertainty on the a priori knowledge of the molecular contribution has been assessed to be lower than $3 \%$ using a comparison between climatic mid-latitude and modeled vertical profiles of temperature. The uncertainty due to LR at $532 \mathrm{~nm}$ has been discussed in several papers (e.g. Raut and Chazette, 2008a). This is a major source of uncertainty depending on the constraint used. In the present paper, LR is considered constant with altitude. The effect of relative humidity on LR, which leads to both the aerosol radius growth and the modification of the complex refractive index, has been shown to be lower than $10 \%$ between $\mathrm{RH}=20 \%$ and $70 \%$ for urban aerosols at $532 \mathrm{~nm}$ (Raut and Chazette, 2008a).

Uncertainty sources (i.e. the random detection processes, the error on $\tau_{\mathrm{MO}}$ and RH effects) have been supposed independent. The error budget on LR has been performed using a Monte Carlo method described in Chazette et al. (2002). The probability density functions of the uncertainty are supposed to follow a normal probability law with standard deviations associated to the SNR at each altitude level and to $\tau_{\mathrm{MO}}$ 
Table 2. Mean value and variability on aerosol LR and extinction coefficient in the PBL retrieved from CALIOP/MODIS-Aqua and Terra synergies and from CALIOP level-2 products.

\begin{tabular}{lllllll}
\hline & & LR $(\mathrm{sr})$ & & \multicolumn{2}{c}{ Aerosol extinction coefficient $\left(\mathrm{km}^{-1}\right)$} \\
data & CALIOP/ & CALIOP/ & CALIOP & CALIOP/ & CALIOP/ & CALIOP \\
& MODIS-Aqua & MODIS-Terra & level-2 & MODIS-Aqua & MODIS-Terra & level-2 \\
\hline day & $70( \pm 11)$ & $74( \pm 14)$ & $63( \pm 9)$ & $0.21( \pm 0.10)$ & $0.24 \pm(0.12)$ & $0.14 \pm(0.08)$ \\
night & $89( \pm 28)$ & $103( \pm 32)$ & $63( \pm 7)$ & $0.17( \pm 0.06)$ & $0.22 \pm(0.08)$ & $0.12 \pm(0.06)$ \\
all & $78( \pm 22)$ & $86( \pm 27)$ & $63( \pm 8)$ & $0.20( \pm 0.09)$ & $0.23 \pm(0.10)$ & $0.13 \pm(0.07)$ \\
\hline
\end{tabular}

Table 3. LR found in the literature for pollution continental and dust aerosols.

\begin{tabular}{|c|c|c|c|c|c|}
\hline Aerosol type & Site/Campaign & Instrumentation & LR & Wavelength & References \\
\hline \multirow{8}{*}{$\begin{array}{l}\text { Pollution } \\
\text { continental }\end{array}$} & Washington State & $\begin{array}{l}180^{\circ} \text { backscatter } \\
\text { nephelometer }\end{array}$ & $60-70 \mathrm{sr}$ & $532 \mathrm{~nm}$ & Doherty et al. (1999) \\
\hline & Bondville (USA) & $\begin{array}{c}180^{\circ} \text { backscatter } \\
\text { nephelometer }\end{array}$ & $\sim 64 \pm 4 \mathrm{sr}$ & $532 \mathrm{~nm}$ & Anderson et al. (2000) \\
\hline & $\begin{array}{c}\text { Sagres island } \\
\text { (Portugal)/ACE } 2\end{array}$ & Raman lidar & $50-70 \mathrm{sr}$ & $532 \mathrm{~nm}$ & Ansmann et al. (2001) \\
\hline & India/INDOEX & & 45 and $75 \mathrm{sr}$ & $532 \mathrm{~nm}$ & Müller et al. (2001) \\
\hline & $\begin{array}{l}\text { AERONET } \\
\text { network }\end{array}$ & sun-photometer & $71 \pm 10 \mathrm{sr}$ & $550 \mathrm{~nm}$ & Cattrall et al. (2005) \\
\hline & $\begin{array}{l}\text { Paris/ESQUIF } \\
\text { and LISAIR }\end{array}$ & $\begin{array}{l}\text { Lidar/sun- } \\
\text { photometer }\end{array}$ & $59-77 \mathrm{sr}$ & $532 \mathrm{~nm}$ & $\begin{array}{c}\text { Chazette et al. (2005) } \\
\text { Raut and Chazette (2007) }\end{array}$ \\
\hline & $\begin{array}{l}\text { Central Europe } \\
\text { EARLINET } \\
\text { network }\end{array}$ & Raman lidar & $50-55 \mathrm{sr}$ & $532 \mathrm{mn}$ & Müller et al. (2007) \\
\hline & Leipzig (Germany) & Raman lidar & $53 \mathrm{sr}$ & $532 \mathrm{~nm}$ & Mattis et al. (2004) \\
\hline \multirow{3}{*}{ Dust } & $\begin{array}{l}\text { AERONET } \\
\text { network }\end{array}$ & sun-photometer & $45 \mathrm{sr}$ & $550 \mathrm{~nm}$ & Cattrall et al. (2005) \\
\hline & $\begin{array}{l}\text { EARLINET } \\
\text { network }\end{array}$ & Raman lidar & $56 \pm 7 \mathrm{sr}$ & 532 & Pappalardo et al. (2010) \\
\hline & $\begin{array}{l}\text { Southern Morocco } \\
\text { /SAMUM }\end{array}$ & Raman lidar & $53 \pm 8 \mathrm{sr}$ & $532 \mathrm{~nm}$ & Tesche et al. (2009) \\
\hline
\end{tabular}

$\left(\sigma_{\mathrm{MO}}\right)$. The sensitivity study on LR due to the uncertainty on the SNR (respectively on $\tau_{\mathrm{MO}}$ ) was thus performed using Monte Carlo simulations based on 1000 Gaussian random realizations of laser shots (resp. optical thicknesses) around the mean value of the SNR in the PBL (resp. of $\tau_{\mathrm{MO}}$ ). Figure 7 shows the results of the Monte Carlo approach involving various SNR values (inside the PBL) ranging from 7 to 30 (Fig. 7a) and different $\sigma_{\mathrm{MO}}$ from 0 to $50 \%$ (Fig. 7b). Several mean AOD at $550 \mathrm{~nm} \tau_{\text {MO }}$ over the Po Valley between 0.05 and 0.45 have been considered in those calculations. In order to assess RH effects, the mean $\mathrm{RH}$ value in the PBL $\left(\mathrm{RH}_{\mathrm{PBL}}\right)$ has been computed from CALIOP level $1 \mathrm{~B}$ relative humidity profile. Several studies (e.g. Raut and Chazette, 2008a) have already shown that LR of pollution aerosols were not affected by low RH values. The uncertainty on LR has been assessed to be $\sim 10 \%$ for $\mathrm{RH}_{\mathrm{PBL}}>55 \%$ and $0 \%$ for $\mathrm{RH}_{\mathrm{PBL}}<55 \%$.

Uncertainties corresponding to each LR value has been computed and reported on Fig. 8a and b taking into account the SNR of the profile, its mean AOD $\tau_{\mathrm{MO}}$ and its standard deviation $\sigma_{\mathrm{MO}}$ and the RH in the PBL. The mean 
(a)

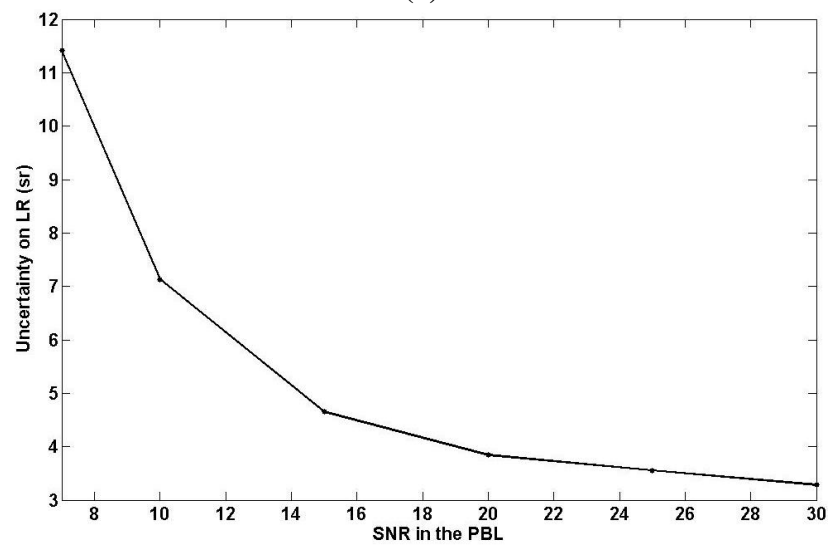

(b)

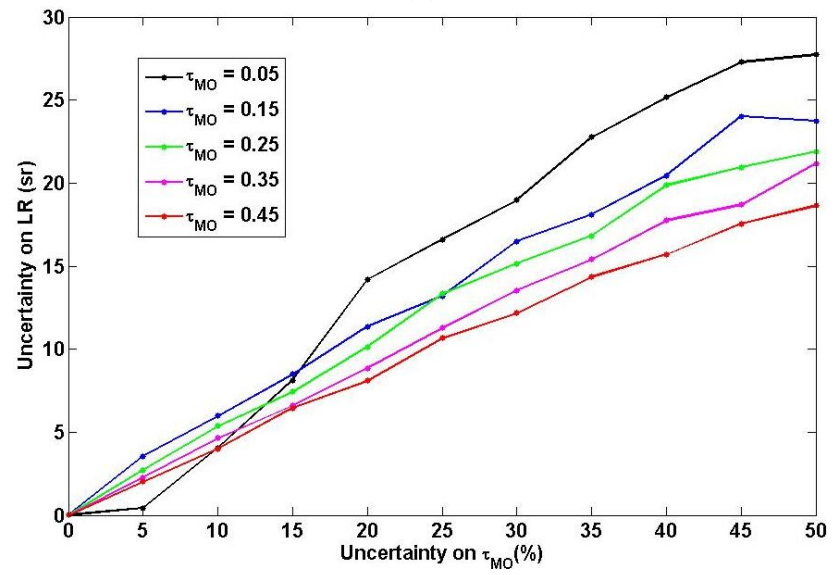

Fig. 7. Results of Monte Carlo simulations to assess the uncertainty on LR retrieval (a) due to the SNR in the PBL of the lidar rangecorrected signal and (b) due to the uncertainty on MODIS-derived AOD $\left(\sigma_{\mathrm{MO}}\right)$ for mean AOD values $\left(\tau_{\mathrm{MO}}\right)$ of $0.05,0.15,0.25,0.35$, 0.45 .

uncertainties on LR are $11.8 \mathrm{sr}$ and $12.2 \mathrm{sr}$ for Aqua and Terra synergies, respectively. The uncertainty on AOD (resp. SNR and RH) contribute to $\sim 62 \%$ (resp. $\sim 23 \%$ and $\sim 15 \%$ ) on the total LR uncertainty.

\section{Results and discussion}

\subsection{LR retrieved over the Po Valley}

The algorithm described in Sect. 4.1 converges in 86 cases among 102 for MODIS-Aqua and 88 cases among 104 for MODIS-Terra. Among the 16 cases where the algorithm did not converge (i.e. not comprised between 20 and 200 sr), 2 were night-time tracks constrained with MODIS daytime AOD and 12 had an AOD lower than 0.1 with uncertainties on $\tau_{\mathrm{MO}}$ higher than $30 \%$ corresponding to uncertainties on LR higher than $15 \mathrm{sr}$. LR occurrences retrieved (a)

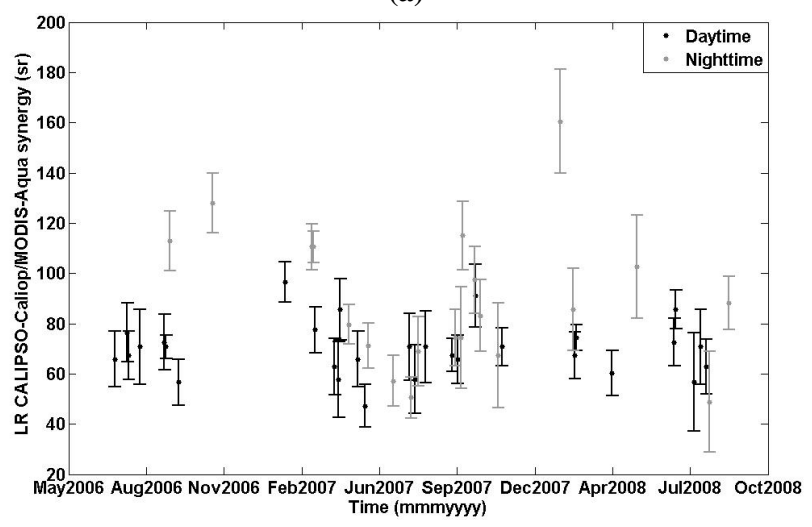

(b)

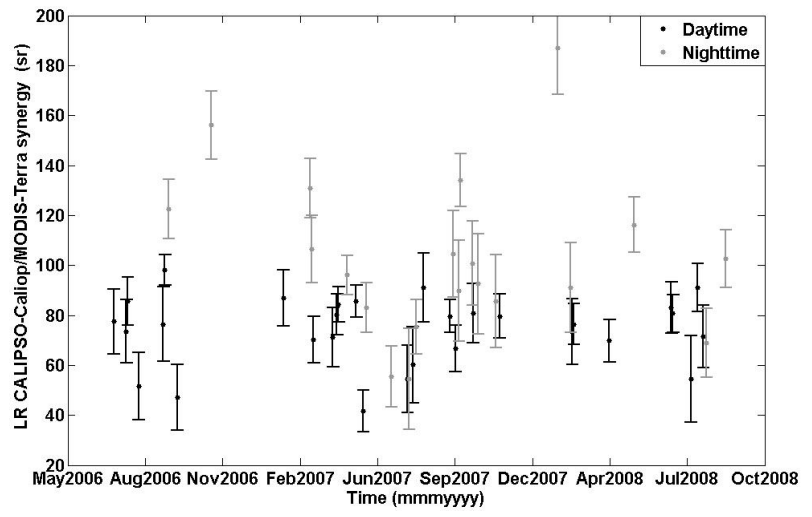

(c)

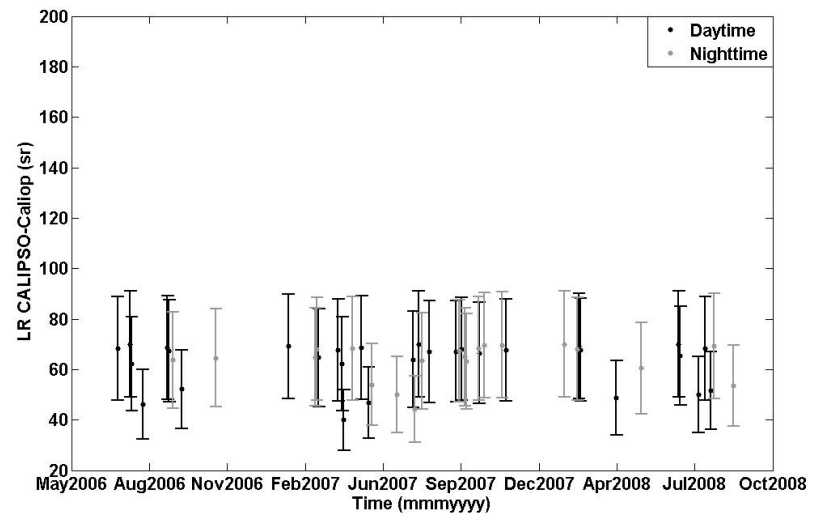

Fig. 8. Temporal evolution from June 2006 to February 2009 of LR values (49 data) over the Po Valley from (a) CALIOP/MODIS-Aqua synergy, (b) CALIOP/MODIS-Terra synergy and (c) CALIOP level-2 products for daytime (dark gray), nighttime (light gray) conditions.

from the synergy are given in Fig. 9a and b. In the histograms, bins as large as $20 \mathrm{sr}$ in the histograms have been chosen accounting for the uncertainties on LR. Daytime and nighttime synergies are represented in dark gray and light gray, respectively. The mean values of aerosol LR and extinction coefficient retrieved from CALIOP/MODIS-Aqua 
a)
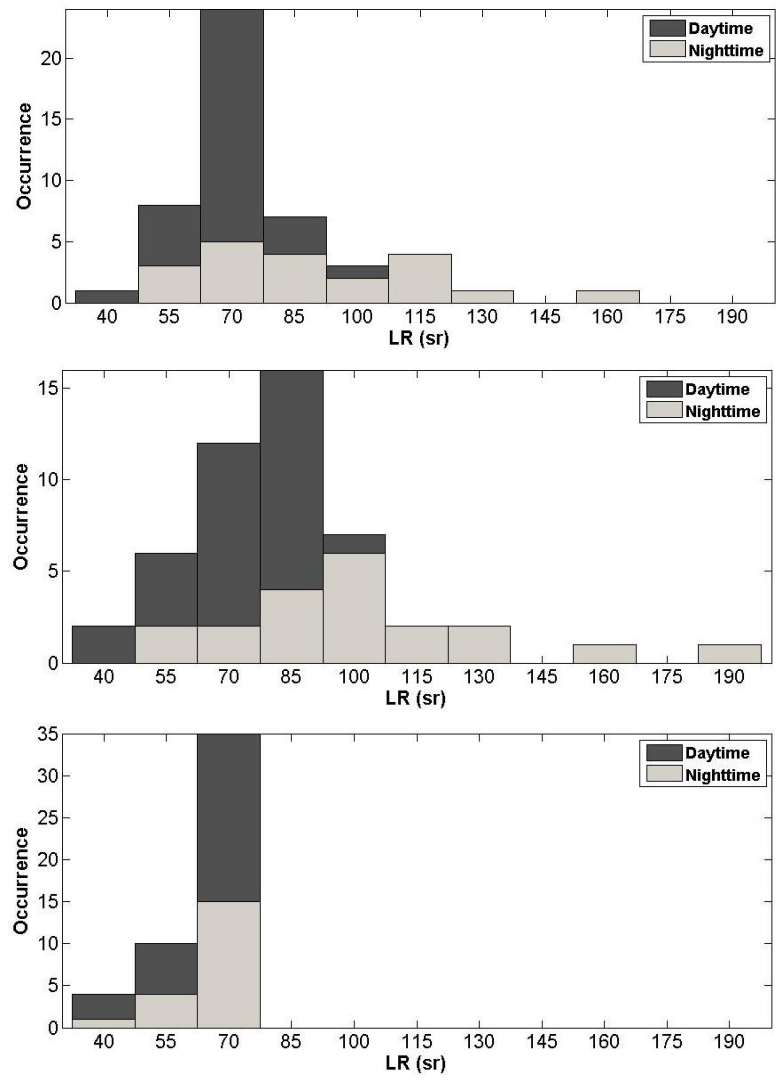

Fig. 9. Occurrences for coincident aerosol LR values (49 data) from (a) CALIOP/MODIS-Aqua synergy, (b) CALIOP/MODISTerra synergy and (c) operational products of CALIOP level-2 for daytime (dark gray), nighttime (light gray).

and Terra synergy and from CALIOP level-2 products are summarized in Table 2. Results from the CALIOP/Aqua and CALIOP/Terra synergies are in agreement at daytime and nighttime. The mean LR (and their variabilities) are indeed close to $78 \pm 22 \mathrm{sr}$ and $86 \pm 27 \mathrm{sr}$ when MODIS-Aqua and MODIS-Terra data are used, respectively. Given that CALIOP and Aqua-MODIS instruments both belong to the A-Train constellation, their temporal coincidence is very good ( $\sim 2 \mathrm{~min})$. The temporal difference increases up to $\sim 1 \mathrm{~h}$ and $40 \mathrm{~min}$ between CALIOP and Terra-MODIS. When CALIPSO orbit passes over the Po Valley at night-time, the MODIS-derived AOD obtained from daytime are the only ones that can be considered. This leads to a temporal difference of about $11 \mathrm{~h}$ (resp. $9 \mathrm{~h}$ and $20 \mathrm{~min}$ ) between CALIPSO and MODIS-Aqua (resp. MODIS-Terra). In this time interval, atmospheric conditions may significantly vary. We can notice than the LR values higher than 100 sr observed correspond to nighttime CALIOP profiles constrained with MODIS daytime AOD. This suggests that in most of cases the synergetic approach is not convincing when nighttime interpolation is performed. If we consider only daytime synergies, the mean LR are $70 \pm 11 \mathrm{sr}$ for CALIOP/Aqua and $74 \pm 14$ sr for CALIOP/Terra synergies.
In order to compare LR retrieved from the spaceborne instrumental synergy CALIOP/MODIS with that determined by CALIOP operational algorithm, the latter needs to be integrated over the vertical column taking into account the relative weight of each aerosol layer in terms of aerosol extinction coefficient. The weighted LR is derived from the operational values of both the aerosol extinction $\left(\alpha_{a i}\right)$ and backscatter $\left(\beta_{a i}\right)$ coefficients following the relation:

$$
\mathrm{LR}=\frac{\sum_{i=1}^{N} \alpha_{a i}}{\sum_{i=1}^{N} \beta_{a i}}
$$

The subscript $i=1$ to $N$ characterizes the altitude level in the CALIOP profile.

The occurrences of LR derived from CALIOP operational product are also given in Fig. 9c. We can notice a minimum threshold of $70 \mathrm{sr}$ corresponding to the minimum available value in the look-up table for polluted continental and biomass burning aerosols. The mean LR value and its the variability of LR are close to $63( \pm 8)$ sr with an uncertainty of $30 \%$. Such a value corresponds to either polluted continental or biomass burning or polluted dust aerosol models. Considering the uncertainties on LR retrieval, this mean value is not far from the one derived from daytime synergies between MODIS and CALIOP since error bars overlap. The agreement between the synergistic approach and operational algorithms is better when using Aqua radiometer. It is also noteworthy that the bias observed between MODIS and the sunphotometer was smaller in this case and that the temporal difference between CALIOP and Aqua is $\sim 2 \mathrm{~min}$ instead of $1 \mathrm{~h} 40 \mathrm{~min}$ for CALIOP and Terra.

Table 3 summarizes different values of LR at $532 \mathrm{~nm}$ found in the literature for pollution and dusts aerosols. LR values retrieved here are typical for pollution aerosol emitted by traffic or industrial activities, which are the main sources of particulate pollution inside the Po valley (Table 1). The Po Valley can also be episodically influenced by longrange transport of dust. The lowest LR values (under $60 \mathrm{sr}$ ) are mainly observed in spring and summer and can be associated to desert dust transport over the Po Valley, which may occur during those seasons. This has been confirmed by backward trajectories performed using the Hysplit model (http://ready.arl.noaa.gov/HYSPLIT.php) and higher depolarization ratio observed with CALIOP lidar (not shown). Dust particles can be transported above Mediterranean Sea as described by Hamonou et al. (1999). Moreover, several dust events have been observed by Bonasoni et al. (2004) at Mt Cimone in the Italian northern Apennines. 


\subsection{Aerosol extinction coefficient retrieved over the Po Valley}

We have compared the vertical profiles of the aerosol extinction coefficient retrieved from the two methods: the MODIS/CALIOP synergy $\left(\alpha_{\mathrm{MO}}\right)$ and the CALIOP level2 operational algorithm. CALIOP level-1 data have been smoothed to obtain almost the same vertical resolution than CALIOP level-2 operational products. To quantify the differences distinguishing the two profiles, we have considered the mean-square error $\left(\Delta_{\alpha}\right)$ in the PBL defined as:

$\Delta_{\alpha}=\sqrt{\frac{1}{N_{\mathrm{PBL}}} \sum_{i=1}^{N_{\mathrm{PBL}}}\left(\alpha_{\mathrm{MO}}-\alpha_{a i}\right)^{2}}$

where $N_{\mathrm{PBL}}$ is the number of CALIOP level-2 data in the PBL.

Two examples of aerosol extinction coefficient on the 15 September 2007 at 12:30 GMT and 8 September 2007 at 12:24 GMT are represented in Fig. 10a and b. These profiles have been averaged in the Po Valley from CALIOP level2 operational product (red lines) and from CALIOP level-1 data inverted with the LR retrieved from the synergy with MODIS (blue lines). In the first case, the two extinction coefficient profiles are in good agreement and $\Delta_{\alpha} \sim 0.02 \mathrm{~km}^{-1}$. LR and AOD derived from MODIS and CALIOP are in good agreement ( $\sim 67 \mathrm{sr}$ and $\sim 0.28$, respectively). A significant discrepancy can be observed in the second example $\left(\Delta_{\alpha} \sim 0.15 \mathrm{~km}^{-1}\right)$. In this last case, the integration of the CALIOP level-2 aerosol extinction profile gives an AOD of 0.20 compared with the value of 0.26 measured by MODISAqua radiometer at the same time. This large underestimation of AOD values can be explained by an underestimation of LR values (67 sr for CALIOP level-2 operational algorithm against $80 \mathrm{sr}$ retrieved from the CALIOP/MODIS synergy).

Occurrences of the mean square difference $\Delta_{\alpha}$ are shown in Fig. 11a and b. One more time, the agreement is better if we consider MODIS-Aqua/CALIOP compared with MODIS-Terra/CALIOP synergy (mean values of the distributions of $0.10 \mathrm{~km}^{-1}$ and $0.13 \mathrm{~km}^{-1}$, respectively). The AOD (and thus the extinction coefficient) is systematically underestimated by the operational algorithm compared with MODIS AOD, suggesting that LR from CALIOP are too low.

\section{Conclusion and perspectives}

Aerosol optical properties have been analyzed over the Po Valley from June 2006 to February 2009 using CALIOP lidar and MODIS-Aqua and Terra radiometers. MODIS-derived aerosol optical depth (AOD) at $550 \mathrm{~nm}\left(\tau_{\mathrm{MO}}\right)$ in the Po Valley have shown a typical seasonal cycle with higher values during spring (0.29) and summer (0.30) and lower values during winter $(0.22)$. The comparison with AERONET sunphotometers has highlighted an overestimation of AOD from (a)

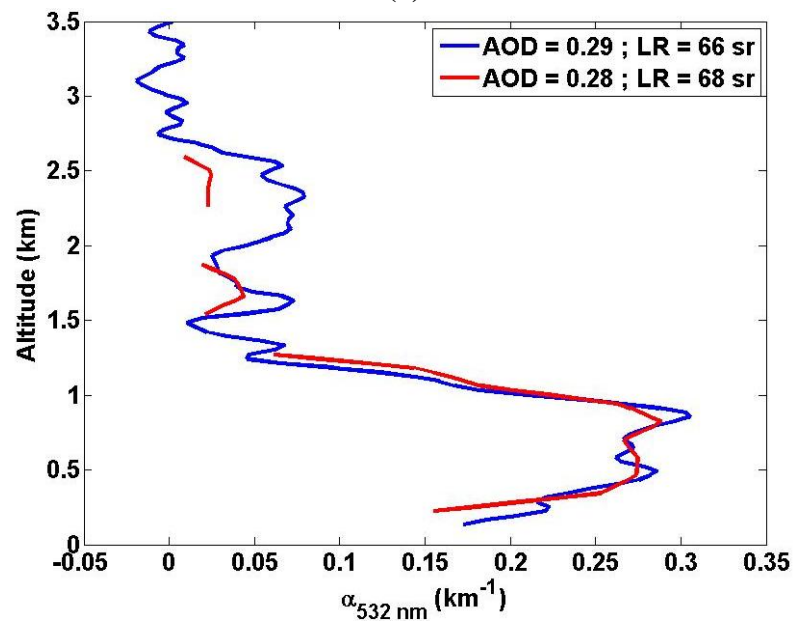

(b)

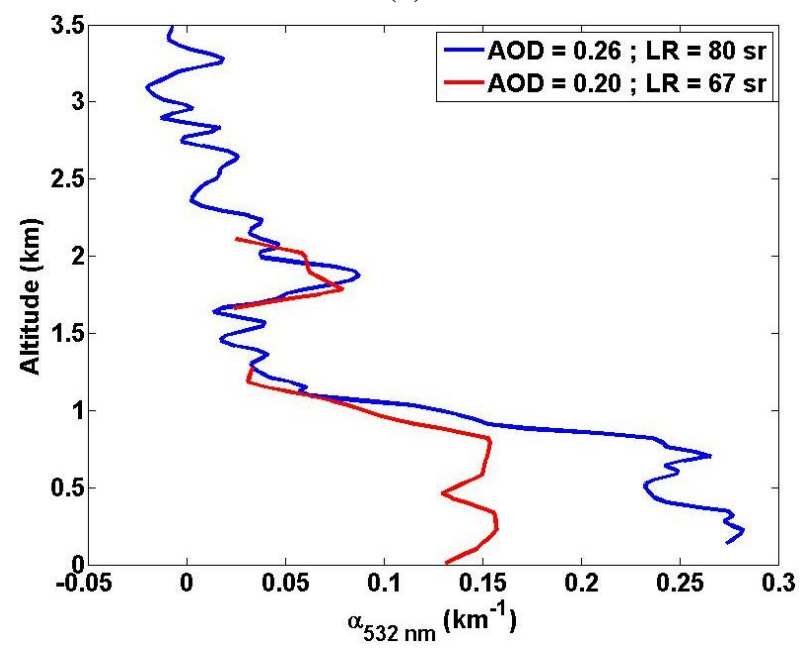

Fig. 10. Mean vertical profiles of aerosol extinction coefficient at $532 \mathrm{~nm}$ on (a) 15 September 2007 at 12:30 GMT and (b) 8 September 2007 at 12:24 GMT. The aerosol extinction coefficient is obtained from CALIOP level-2 operational product (red line) and from CALIOP level-1 data inverted with the LR retrieved from the synergy with MODIS (blue line).

MODIS radiometers of 0.047 for Aqua and 0.088 for Terra. A systematic underestimation of AOD derived from CALIOP Level-2 products has been observed in comparison to Aqua (0.060) and Terra (0.075) MODIS values. Considering those discrepancies a synergistic approach combining CALIOP level-1 data and MODIS AOD has been developed for the first time over land to retrieve the equivalent extinction-tobackscatter ratio at $532 \mathrm{~nm}$ (LR). MODIS-derived AOD were indeed used to constrain CALIOP profiles inversion. The mean LR retrieved for both daytime and nighttime synergies are $\sim 78( \pm 22)$ sr for AOD from MODIS-Aqua data are used and $\sim 86( \pm 27)$ sr with Terra data. The total uncertainty 
(a)

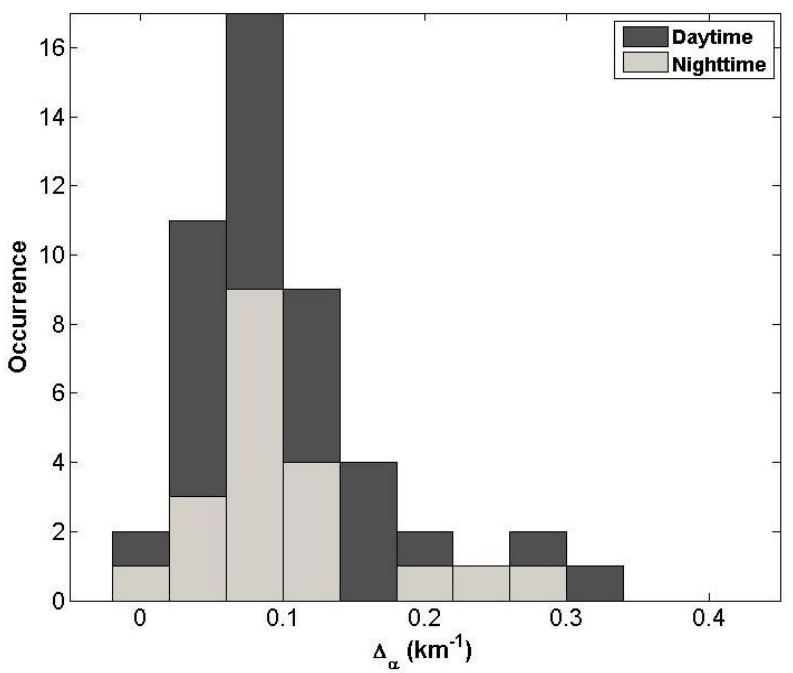

(b)

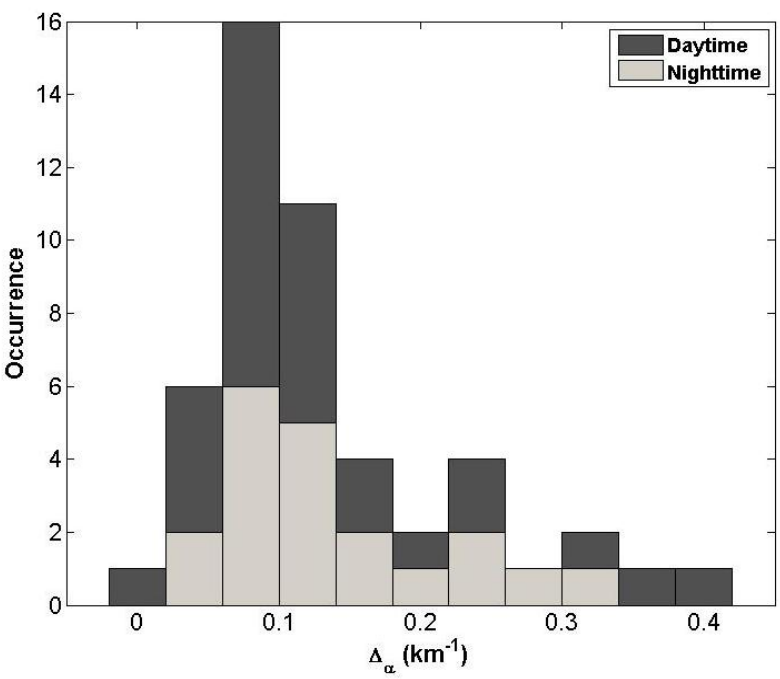

Fig. 11. Occurrence of the mean-square error $\left(\Delta_{\alpha} \mathrm{p}\right.$ in the PBL between aerosol extinction coefficient retrieved from (a) CALIOP level-2 and MODIS-Aqua/CALIOP synergy and (b) CALIOP level2 and MODIS-Terra/CALIOP synergy for daytime (light gray), night-time (black) and all data (dark gray).

on LR retrieval has been assessed to be $\sim 12$ sr using Monte Carlo simulations. The mean LR determined from a look-up table with a selection algorithm in CALIOP level 2 operational products $(\sim 63 \pm 8 \mathrm{sr})$ show a good agreement for daytime inversion ( $70 \pm 11 \mathrm{sr}$ for Aqua and $74 \pm 14 \mathrm{sr}$ for Terra). These values appear close to what is expected for pollution aerosols in an urban area. Contrarily large differences are observed when considering nighttime CALIOP profiles inverted with daytime AOD from MODIS (63 $\pm 7 \mathrm{sr}$ for CALIOP level-2 compared with $89 \pm 28$ sr for CALIOP/Aqua and $103 \pm 32$ sr for CALIOP/Terra synergies). They can be explained by a significant evolution of AOD between lidar and radiometer passing times. The lowest LR values (under $60 \mathrm{sr}$ ) are mainly observed in spring and summer and can be associated to desert dust transport over the Po Valley, which can occur at these seasons. This is validated by higher depolarization ratio (not shown) observed with CALIOP lidar at the same time. The use of AOD from MODIS radiometers in synergy with CALIOP lidar provides a good alternative to CALIOP profiles inversion and would deserve to be applied to other regions in order to assess the reliability of CALIOP operational algorithm on various aerosol types.

The synergy considered in this paper shows the potential of such an approach to survey large polluted area. The main limitation is due to the signal to noise ratio and the uncertainty on AOD constraint that requires to average CALIOP and MODIS data along the track on several tens of kilometres. Hence, the polluted area must cover a region larger than $100 \mathrm{~km}$. The synergy between active and passive spaceborne instruments dedicated to the Earth survey promises an important development in the next decades. Such a synergy between CALIPSO/CALIOP and MODIS/Aqua or Terra is a powerful tool to apprehend the evolution of the Earth system influenced by human activities. Moreover, this study will be a great insight in the context of the validation of the further ADM-AEOLUS program scheduled to be launched at the end of 2012 (http://www.esa.int/esaLP/LPadmaeolus.html), which requires significant loads of particles to validate the aerosol products.

Acknowledgements. This work was supported by the Comissariat à l'Energie Atomique (CEA) and the Centre National d'Etudes Spatiales (CNES). The authors would like to thank MODIS science data support team for processing level 2 data, and AERONET for collecting aerosol observations around the world and especially Giuseppe Zibordi the principal investigator of the Ispra site. CALIOP data were obtained from the NASA Langley Research Center Atmospheric Science Data Center (ASDC) via on-line web orders. We are very grateful to the entire CALIPSO science team for providing CALIOP data.

Edited by: A. A. Kokhanovsky

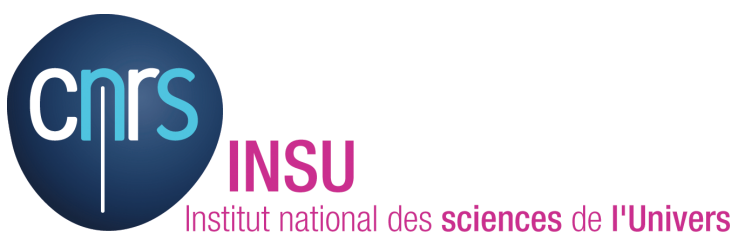

The publication of this article is financed by CNRS-INSU. 


\section{References}

Anderson, T. L., Masonis, S. J., Covert, D. S., Charlson, R. J., and Rood, M. J.: In situ measurement of the aerosol extinction-tobackscatter ratio at a polluted continental site, J. Geophys. Res., 105(D22), 20907-20915, 2000.

Angström, A.: The parameters of atmospheric turbidity, Tellus, 16, 64-75, 1964.

Ansmann, A., Wandinger, U., Riebesell, M., Weitkamp, C., and Michaelis, W.: Independent measurement of extinction and backscatter profiles in cirrus clouds by using a combined Raman elastic-backscatter lidar, Appl. Optics, 31, 7113-7113, 1992.

Ansmann, A., Wagner, F., Althausen, D., Müller, D., Herber, A., and Wandinger, U.: European pollution outbreaks during ACE 2: Lofted aerosol plumes observed with Raman lidar at the Portuguese coast, J. Geophys. Res., 106(D18), 20725-20733, 2001, doi:10.1029/2000JD000091.

Balis, D., Giannakaki, E., Müller, D., Amiridis, V., Kelektsoglou, K. Rapsomanikis, S., and Bais, A.: Estimation of the microphysical aerosol properties over Thessaloniki, Greece, during the SCOUT-O 3 campaign with the synergy of Raman lidar and Sun photometer data, J. Geophys. Res., 115, D08202, doi:10.1029/2009JD013088, 2010.

Barnaba, F. and Gobbi, G. P.: Aerosol seasonal variability over the Mediterranean region and relative impact of maritime, continental and Saharan dust particles over the basin from MODIS data in the year 2001, Atmos. Chem. Phys., 4, 2367-2391, doi:10.5194/acp-4-2367-2004, 2004.

Berthier, S., Chazette, P., Couvert, P., Pelon, J., Dulac, F., Thieuleux, F., Moulin, C., and Pain, T.: Desert dust aerosol columnar properties over ocean and continental Africa from Lidar in-Space Technology Experiment (LITE) and Meteosat synergy, J. Geophys. Res., 111, D21202, doi: 10.1029/2005JD006999, 2006.

Berthier, S., Chazette, P., Pelon, J., and Baum, B.: Comparison of cloud statistics from spaceborne lidar systems, Atmos. Chem. Phys., 8, 6965-6977, doi:10.5194/acp-8-6965-2008, 2008.

Bonasoni, P., Cristofanelli, P., Calzolari, F., Bonafé, U., Evangelisti, F., Stohl, A., Zauli Sajani, S., van Dingenen, R., Colombo, T., and Balkanski, Y.: Aerosol-ozone correlations during dust transport episodes, Atmos. Chem. Phys., 4, 1201-1215, doi:10.5194/acp-4-1201-2004, 2004.

Cattrall, C., Reagan, J., Thome, K., and Dubovik, O.: Variability of aerosol and spectral lidar and backscatter and extinction ratios of key aerosol types derived from selected Aerosol Robotic Network locations, J. Geophys. Res., 110, D10S11, doi:10.1029/2004JD005124, 2005.

Chazette, P., David, C., Lefrère, J., Godin, S., Pelon, J., and Mégie, G.: Comparative lidar study of the optical, geometrical, and dynamical properties of stratospheric post-volcanic aerosols, following the eruption of El Chichon and Mount Pinatubo, J. Geophys. Res., 100(D11), 23195-23207, 1995.

Chazette, P., Pelon, J., Moulin, C., Dulac, F., Carrasco, I., Guelle, W., Bousquet, P., and Flamant, P.H. : Lidar and satellite retrieval of dust aerosols over the azores during SOFIA/ASTEX, Atmos. Environ., 35, 4297-4304, 2001.

Chazette, P., Pelon, J., and Mégie, G.: Determination by spaceborne backscatter lidar of the structural parameters of atmospheric scattering layers, Appl. Optics, 40, 3428-3440, 2002.

Chazette, P.: The monsoon aerosol extinction properties at Goa dur- ing INDOEX as measured with lidar, J. Geophys. Res., 108 (D6), 4187, doi:10.1029/2002JD002074, 2003.

Chazette, P., Randriamiarisoa, H., Sanak, J., Couvert P., and Flamant, C.: Optical properties of urban aerosol from airborne and ground-based in situ measurements performed during the ESQUIF program, J. Geophys. Res, 110(D2), D0220610.1029/2004JD004810, 2005.

Chazette, P., Sanak, J., and Dulac, F.: New Approach for Aerosol Profiling with a Lidar Onboard an Ultralight Aircraft: Application to the African Monsoon Multidisciplinary Analysis, Environ. Sci. Technol., 41(24), 8335-8341, doi:10.1021/es070343y, 2007.

Chazette, P., Raut, J.-C., Dulac, F., Berthier, S., Kim, S.-W., Royer, P., Sanak, J., Loaëc, S., and Grigaut-Desbrosses, H.: Simultaneous observations of lower tropospheric continental aerosols with a ground-based, an airborne, and the spaceborne CALIOP lidar systems, J. Geophys. Res., Special issue on CALIPSO data, doi:10.1029/2009JD012341, 2010.

Chu, D. A., Kaufman, Y. J., Ichoku, C., Remer, L. A., Tanré, D., and Holben, B. N.: Validation of MODIS aerosol optical depth retrieval over land, Geophys. Res. Lett., 29(12), 8007, doi:10.1029/2001GL013205, 2002.

Dockery, D. and Pope, A.: Epidemiology of acute health effects: summary of time-series, in: Particles in Our Air: Concentration and Health Effects, edited by: Wilson, R. and Spengler, J. D., Harvard University Press, Cambridge, MA, USA, 123-147, 1996.

Dulac, F. and Chazette, P.: Airborne study of a multi-layer aerosol structure in the eastern Mediterranean observed with the airborne polarized lidar ALEX during a STAAARTE campaign (7 June 1997), Atmos. Chem. Phys., 3, 1817-1831, doi:10.5194/acp-31817-2003, 2003.

Hamonou, E., Chazette, P., Balis, D., Dulac, F., Schneider, X., Galani, E., Ancellet, G., and Papayannis, A.: Characterisation of the vertical structure of Saharan dust export to the Mediterranean basin, J. Geophys. Res., 18, 2257-2270, 1999.

Haywood, J. M., Pelon, J., Formentiet, P., et al.: Overview of the dust and biomass-burning experiment and African Monsoon Multidisciplinary Analysis special observing period-0, J. Geophys. Res., 113, D00C17, doi:10.1029/2008JD010077, 2008.

Highwood, E. J., Haywood, J. M., Coe, H., Cook, J., Osborne, S., Williams, P., Crosier, J., Formenti, P., McQuaid, J., Brooks, B., Thomas, G., Grainger, R., Barnaba, F., Gobbi, G. P., and De Leeuw, G.: Aerosol Direct Radiative Impact Experiment (ADRIEX) overview., Q. J. Roy. Meteor. Soc., 133(S1), 3-15, 2007.

Holben, B. N., Eck, T. F., Slutsker, I., Tanré, D., Buis, J. P., Setzer, A., Vermote, E., Reagan, J. A., Kaufman, Y., Nakajima, T., Lavenu, F., Jankowiak, I., and Smirnov, A.: AERONET - A federated instrument network and data archive for aerosol characterization., Rem. Sens. Environ., 66, 1-16, 1998.

Jeong, M.-J. and Hsu, N. C.: Retrievals of aerosol single-scattering albedo and effective aerosol layer height for biomass-burning smoke: Synergy derived from “A-Train” sensors, Geophys. Res. Lett., 35, L24801, doi:10.1029/2008GL036279, 2008.

Klett, J. D.: Lidar inversion with variable backscatter/extinction ratios, Appl. Optics, 24, 1638-1643,1985.

King, M. D., Kaufman, Y. J., Menzel, W. P., and Tanre, D.: Remote sensing of cloud, aerosol, and water vapor properties from the 
Moderate Resolution Imaging Spectrometer (MODIS), IEEE T. Geosci. Remote, 30(1), 2-27, 1992.

Kim, S.-W., Yoon, S.-C., Kim, J., and Kim, S.-Y.: Seasonal and monthly variations of columnar aerosol optical properties over east Asia determined from multi-year MODIS, LIDAR and AERONET Sun/sky radiometer measurements, Atmos. Environ., 41, 1634-1651, 2007.

Kim, S.-W., Berthier, S., Raut, J.-C., Chazette, P., Dulac, F., and Yoon, S.-C.: Validation of aerosol and cloud layer structures from the space-borne lidar CALIOP using a ground-based lidar in Seoul, Korea, Atmos. Chem. Phys., 8, 3705-3720, doi:10.5194/acp-8-3705-2008, 2008.

Laaksonen, A., Hamed, A., Joutsensaari, J., Hiltunen, L., Cavalli, F., Junkermann, W., Asmi, A., Fuzzi, S., and Facchini, M. C.: Cloud condensation nucleus production from nucleation events at a highly polluted region, Geophys. Res. Lett., 32, L06812, doi:10.1029/2004GL022092, 2005.

Lauwerys, R. R. : Toxicologie industrielle et intoxications professionnelles, Masson, 1982.

Lawrence, M. G., Butler, T. M., Steinkamp, J., Gurjar, B. R., and Lelieveld, J.: Regional pollution potentials of megacities and other major population centers, Atmos. Chem. Phys., 7, 39693987, doi:10.5194/acp-7-3969-2007, 2007.

Liu, Z., Omar, A., Vaughan, M., Hair, J., Kittaka, C., Hu, Y., Powell, K., Trepte, C., Winker, D., Hostetler, C., Ferrare, R., and Pierce, R.: CALIPSO lidar observations of the optical properties of Saharan dust: A case study of long-range transport, J. Geophys. Res., 113, D07207, doi:10.1029/2007JD008878, 2008.

Mattis, I., Ansmann, A., Müller, D., Wandinger, U., and Althausen, D.: Multiyear aerosol observations with dual wavelength Raman lidar in the framework of EARLINET, J. Geophys. Res., 109, doi:10.1029/2004JD004600, 2004.

Measures, R. M.: Laser remote sensing: Fundamentals and Applications, Wiley and Sons, New York, 1984.

Mélin, F. and Zibordi G.: Aerosol variability in the Po Valley analyzed from automated optical measurements, Geophys. Res. Lett., 32, L03810, doi:10.1029/2004GL021787, 2005.

Müller, D., Franke, K., Wagner, F., Althausen, D., Ansmann, A., Heintzenberg, J., and Verver G.: Vertical profiling of optical and physical particle properties over the tropical Indian Ocean with six-wavelength lidar 2. Case studies, J. Geophys. Res., 106(D22), 28577-28595, 2001

Müller, D., Ansmann, A., Mattis, I., Tesche, M., Wandinger, U., Althausen, D., and Pisani, G.: Aerosol-type-dependent lidar ratios observed with Raman lidar, J. Geophys. Res., 112, D16202, doi:10.1029/2006JD008292, 2007.

Neftel, A., Spirig, C., Prevot, A. S. H., Furger, M., Stutz, J., Vogel, B., and Hjorth, J.: Sensitivity of photooxidant production in the Milan Basin: An overview of results from a EUROTRAC-2 Limitation of Oxidant Production field experiment, J. Geophys. Res., 107, 8188, doi:10.1029/2001JD001263, 2002.

Noel, V., Hertzog, A., Chepfer, H., and Winker, D. M.: Polar stratospheric clouds over Antarctica from the CALIPSO spaceborne lidar, J. Geophys. Res., 113, D02205, doi:10.1029/2007JD008616, 2008.

Omar, A., Winker, D., Kittaka, C., Vaughan, M., Liu, Z., Hu, Y., Trepte, C., Rogers, R., Ferrare, R., Kuehn, R., Hostetler, C.: The CALIPSO Automated Aerosol Classification and Lidar Ratio Selection Algorithm, J. Atmos. Ocean. Tech., 26, 1994-2014, doi:
10.1175/2009JTECHA1231.1, 2009.

Pappalardo, G., Wandinger, U., Mona, L., Hiebsch, A., Mattis, I., Amodeo, A., Ansmann, A., Seifert, P., Linne, H., Apituley, A., Alados Arboledas, L., Balis, D., Chaikovsky, A., D’ Amico, G., De Tomasi, F., Freudenthaler, V., Giannakaki, E., Giunta, A., Grigorov, I., Iarlori, M., Madonna, F., Mamouri, R.-E., Nasti, L., Papayannis, A., Pietruczuk, A., Pujadas, M., Rizi, V., Rocadenbosch, F., Russo, F., Schnell, F., Spinelli, N.,Wang, X., and Wiegner, M.: EARLINET correlative measurements for CALIPSO: First intercomparison results, J. Geophys. Res., doi:10.1029/2009JD012147, 2009.

Pelon, J., Flamant, C., Chazette, P., Léon, J. F., Tanré, D., Sicard, M., and Satheesh, S. K.: Characterization of aerosol spatial distribution and optical properties over the Indian Ocean from airborne lidar and radiometry during INDOEX'99, J. Geophys. Res., 107(D19), 8029, doi:10.1029/2001JD000402, 2002.

Petritoli, A., Bonasoni, P., Giovanelli, G., Ravegnani, F., Kostadinov, I., Bortoli, D., Weiss, A., Schaub, D., Richter, D., and Fortezza, F.: First comparison between groundbased and satellite-borne measurements of tropospheric nitrogen dioxide in the Po basin, J. Geophys. Res., 109, D15307, doi:10.1029/2004JD004547, 2004.

Ramachandran, S.: Aerosol optical depth and fine mode fraction variations deduced from Moderate Resolution Imaging Spectroradiometer (MODIS) over four urban areas in India, J. Geophys. Res., 112, D16207, doi:10.1029/2007JD008500, 2007.

Raut, J.-C. and Chazette, P.: Retrieval of aerosol complex refractive index from a synergy between lidar, sunphotometer and in situ measurements during LISAIR experiment, Atmos. Chem. Phys., 7, 2797-2815, doi:10.5194/acp-7-2797-2007, 2007.

Raut, J.-C. and Chazette, P.: Vertical profiles of urban aerosol complex refractive index in the frame of ESQUIF airborne measurements, Atmos. Chem. Phys., 8, 901-919, doi:10.5194/acp8-901-2008, 2008a.

Raut, J.-C. and Chazette, P.: Radiative budget in the presence of multi-layered aerosol structures in the framework of AMMA SOP-0, Atmos. Chem. Phys., 8, 6839-6864, doi:10.5194/acp-86839-2008, 2008b.

Salmonson, V. V., Barnes, W. L., Maymon, P. W., Montgomery, H. E., and Ostrow, H.: MODIS: Advanced Facility Instrument for Studies of the Earth as a System, IEEE T. Geosci. Remote, 27, 145-153, 1989.

Sassen, K., Wang, Z., and Liu, D.: Global distribution of cirrus clouds from CloudSat/Cloud-Aerosol Lidar and Infrared Pathfinder Satellite Observations (CALIPSO) measurements, J. Geophys. Res., 113, D00A12, doi:10.1029/2008JD009972, 2008

Sicard, M., Chazette, P., Pelon, J., Won, J. G., and Yoon, S.-C.: Variational method for the retrieval of the optical thickness and the backscatter coefficient from multiangle lidar profiles, Appl. Optics, 41, 493-502, 2002.

Stammes, P. and Henzing, J.: Multispectral aerosol optical thickness at De Bilt 1997-1999, J. Aerosol Sci, 31, 283-284, 2000.

Stephens, G. L., Vane, R. J., Boain, R. J., Mace, G. G., Sassen, K., Wang, Z. E., Illingworth, A. J., O'Connor, E. J., Rossow, W. B., Durden, S. L., Miller, S. D., Austin, R. T., Benedetti, A., and Mitrescu, C.: The CloudSat mission and the A-Train: A new dimension of space-based observations of clouds and precipitation, B. Am. Meteorol. Soc., 83, 1771-1790, 2002. 
Tesche, M., Ansmann, A., Müller, D., Althausen, D., Mattis, I., Heese, B., Freudenthaler, V., Wiegner, M., Esselborn, M., Pisani, G., and Knippertz, P.: Vertical profiling of Saharan dust with Raman lidars and airborne HSRL in southern Morocco during SAMUM, Tellus B, 61(1), 144-164, 2009.
Thomason, L. W., Pitts, M. C., and Winker, D. M.: CALIPSO observations of stratospheric aerosols: a preliminary assessment, Atmos. Chem. Phys., 7, 5283-5290, doi:10.5194/acp-7-52832007, 2007.

Winker, D. M., Pelon, J., and McCormick, M. P.: The CALIPSO mission: Spaceborne lidar for observation of aerosols and clouds, Proc. SPIE, 4893, 1-11, 2003. 